\title{
Riggia acuticaudata sp. nov. (Isopoda, Cymothoidae) from the body cavity of a reshwater fish of Mato Grosso do Sul State, Brazil ${ }^{1}$
}

\author{
Vernon E. Thatcher ${ }^{2}$ \\ Luiza Paula C. Lopes ${ }^{3}$ \\ Otavio Froehlich ${ }^{3}$
}

\begin{abstract}
Riggia acuticaudata sp. nov. is described on the basis of 10 female specimens recovered from the body cavity of the freshwater catfish, Ancistrus sp. The fish were caught in a stream called the Córrego Piraputanga, a tributary of the Paraguai River. The new species differs from the others in the genus by being smaller and less convex and by having a pleotelson that tapers abruptly rather than being the same width throughout. Also, the pereopods and dactyls are much smaller, the maxillule has two terminal and three subterminal spines and the first two pleopods are elongate and acute. Additionally, $R$. acuticaudata sp. nov. is from a different Order of fish host and a new geographic area

KEY WORDS. Isopod parasite, cymothoid, fish parasite, Brazil
\end{abstract}

According to THATCHER (2000), 20 species of freshwater cymothoids occur in Brazil. Of these, three are species of Riggia Szidat, 1948. The latter genus was proposed for a species in which the pleon and pleotelson are fused to form a single unit in adult females. He called the type species Riggia paranensis Szidat, 1948 because the host fish was from the Paraná River in Argentina. In a later paper (SZIDAT \& SCHUBART 1960), two additional species were described from fishes of São Paulo State, Brazil. BASTOS \& THATCHER (1997) redescribed the type species based on specimens from Rio de Janeiro State, Brazil, and emended the generic diagnosis. The present paper describes a new species of Riggia from a catfish of Mato Grosso do Sul State, Brazil.

\section{MATERIAL AND METHODS}

The cymothoids were removed from the fish hosts and preserved in $70 \%$ alcohol. Mouthparts and other appendages were removed with dissecting needles and cleared in pure phenol for study in temporary mounts. Permanent preparations were made of some appendages utilizing the phenol-balsam method described in THATCHER (1991). Photographs were taken with a digital camera at 5,000 pixels and drawings of the smaller parts were made with the aid of a camera lucida. Measurements are in micrometers $(\mu \mathrm{m})$ unless designated as millimeters $(\mathrm{mm})$.

1) Contribution number 1404 of the Departamento de Zoologia, Universidade Federal do Paraná.

2) Departamento de Zoologia, Universidade Federal do Paraná. Caixa Postal 19020, 81531-980 Curitiba, Paraná, Brasil. Research Fellow of the CNPq.

3) Departamento de Biologia, Universidade Federal de Mato Grosso do Sul. Caixa Postal 549, 79070-900 Campo Grande, Mato Grosso do Sul, Brasil. 


\section{Riggia Szidat, 1948}

Generic diagnosis (adapted from BASTOS \& THATCHER 1997). Female: body more or less convex dorsally. Cephalon partially immersed in pereonite 1. Coxal plates small; pereopods short; $7^{\text {th }}$ pair of dactyls not clawlike. Second pleopods with appendix masculinum modified to form accessory gill. Pleon and pleotelson fused, partially immersed in pereonite 7. Uropods long and tapering.

Male. Body much smaller than female, less convex dorsally. Appendix masculinum of second pleopod slender and pointed. Pleon and pleotelson not fused and not immersed in pereonite 7 .

\section{Riggia acuticaudata sp. nov.}

Figs 1-22

Host. Ancistrus sp. (Loricariidae).

Site. Body cavity.

Locality. Córrego Piraputanga, Mato Grosso do Sul State, Brazil.

Intensity. One to two individuals per host fish.

Type material. Holotype female and four Paratype females deposited in the Crustacean Collection of the Instituto Nacional de Pesquisas da Amazônia (INPA) Manaus, Brazil, (INPA 894-899) and three paratype females in the Invertebrate Zoology Collection of the Universidade Federal do Mato Grosso do Sul Biology Department, Campo Grande, Mato Groasso do Sul, Brazil.

Etymology. The species name is in reference to the sharply acute pleotelson.

Species diagnosis (based on 10 females; measurements in table I): Body small, convex dorsally; widest at level of pereonite 3; pereonite 1 longest, 7 shortest, $2-5$ subequal in length (Fig. 1). Cephalon immersed in pereonite 1; eyes prominent; frons rounded (Fig. 3). Antennule (Fig. 4) shorter than antenna, composed of eight articles. Antenna (Fig. 5) slender, of eight articles. Mouthparts (Figs 7-10): maxilliped with lateral setae, palp without spination; maxilla bilobed with two prominent spines on each lobe; maxillule with five recurved spines, two of which are terminal and three are subterminal; mandible "foot-shaped" with few lateral spinules terminally, palp of three articles, subequal in length to mandible. Pereopods (Figs 6, 11-16) short and stout; curved clawlike dactyls on 1-6; dactyl 7 simple, not clawlike. Pleon and pleotelson fused, immersed in pereonite 7; pleotelson pointed (Fig. 1). Pleopods (Figs 17-21): pleopods 1-2 elongate, pointed with elongate endopods; pleopodal endopod 2 bilaminate; pleopodal endopods 19-21 ovoidal; pleopodal exopods 3-5 shorter than 1-2. Uropod with elongate rami, endopod shorter than exopod.

Male. Unknown.

\section{DISCUSSION}

Of the described species in the genus, $R$. paranensis was reported to be 14-28 $\mathrm{mm}$ long and 10-20 mm wide (BASTOS \& THATCHER 1997); $R$. brasiliensis $33 \times 23$ $\mathrm{mm}$ and $R$. nana $14 \times 10 \mathrm{~mm}$ (SZIDAT \& SCHUBART 1960). Therefore, $R$. acuticaudata sp. nov. is similar in size to the latter species but much smaller than the other two. The new species differs from all three, however, in that the pleon/pleotelson 

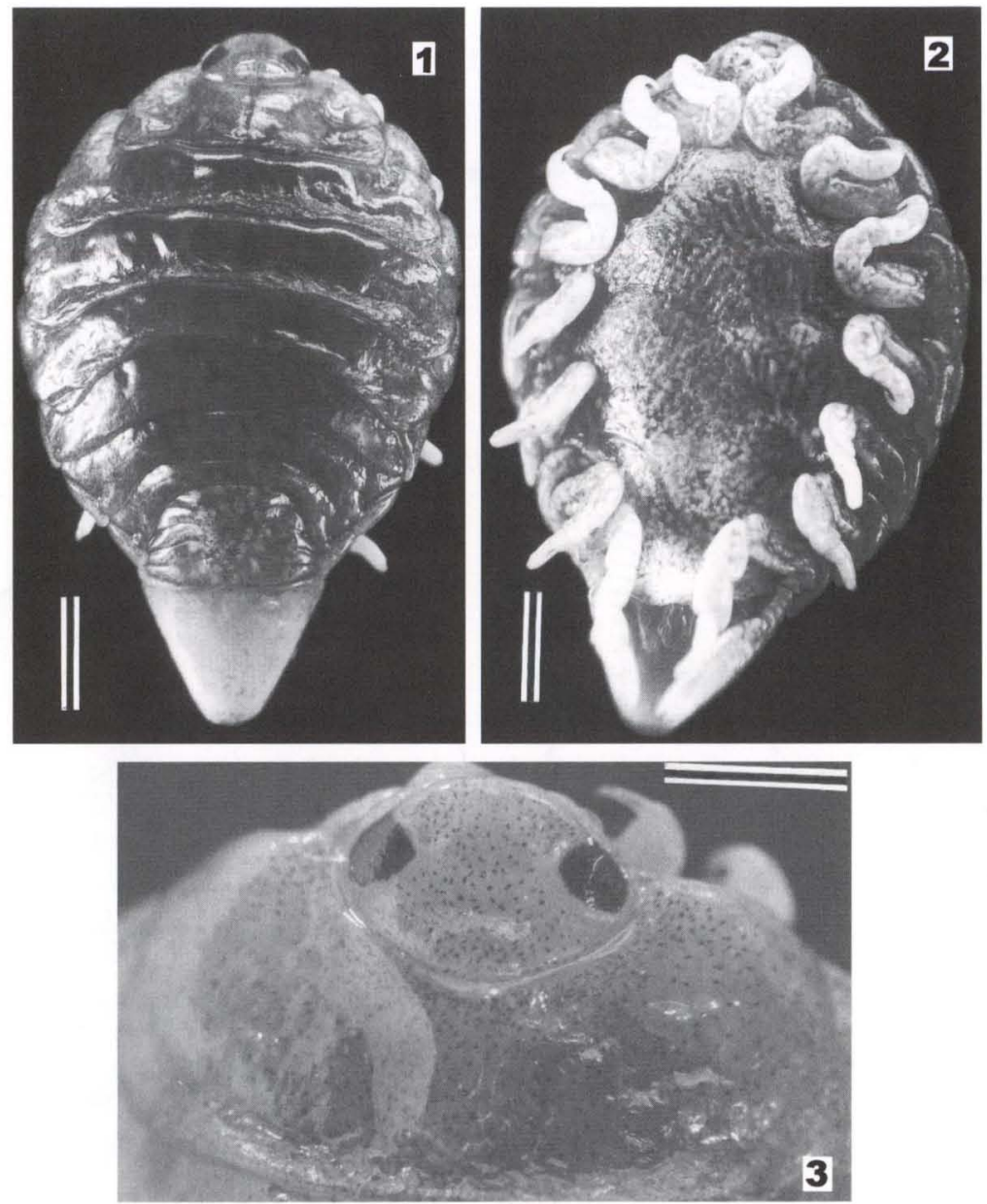

Figs 1-3. 1. Riggia acuticaudata sp. nov., female: (1) dorsal view, (2) ventral view, (3) dorsal view of cephalon and pereonite 1 . Scales $1-2=2 \mathrm{~mm}, 3=1 \mathrm{~mm}$.

Table I. Measurements (mm) of nine females of Riggia acuticaudata sp. nov.

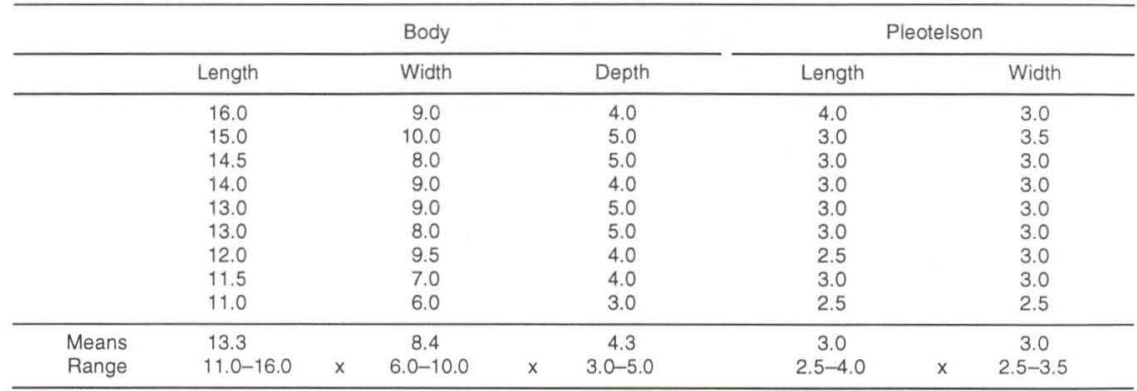

Revta bras. Zool. 19 (Supl. 2): 195 - 201, 2002 


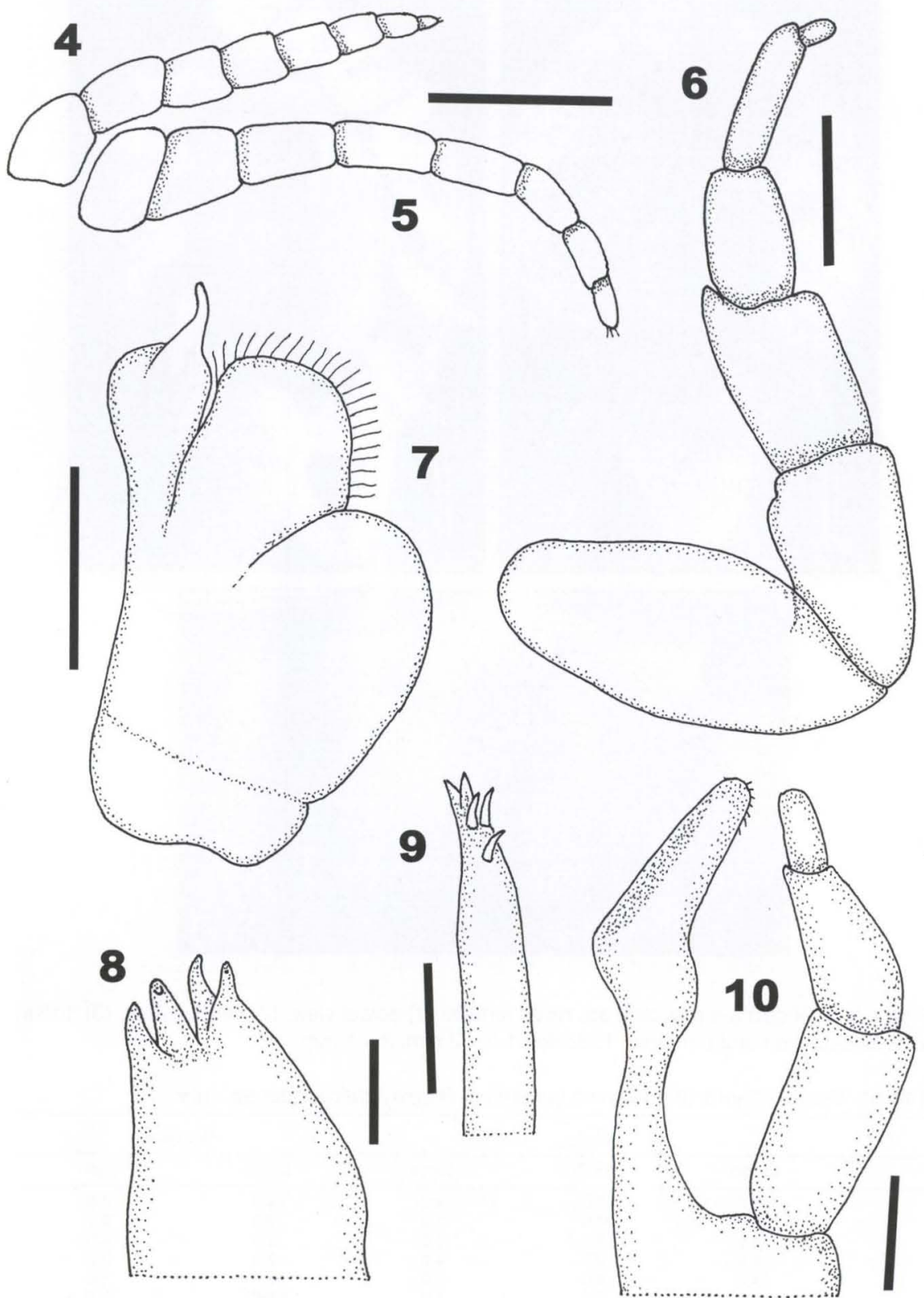

Figs 4-10. Riggia acuticaudata sp. nov., female: (4) antennule, (5) antenna, (6) pereopod 7 , (7) maxilliped, (8) maxilla, (9) maxillule, (10) mandible and palp. Scales: 4-5 =500 $\mu \mathrm{m}, 6-7=$ $1 \mathrm{~mm} ; 8-9=100 \mu \mathrm{m}, 10=200 \mu \mathrm{m}$.

Revta bras. Zool. 19 (Supl. 2): 195 - 201, 2002 

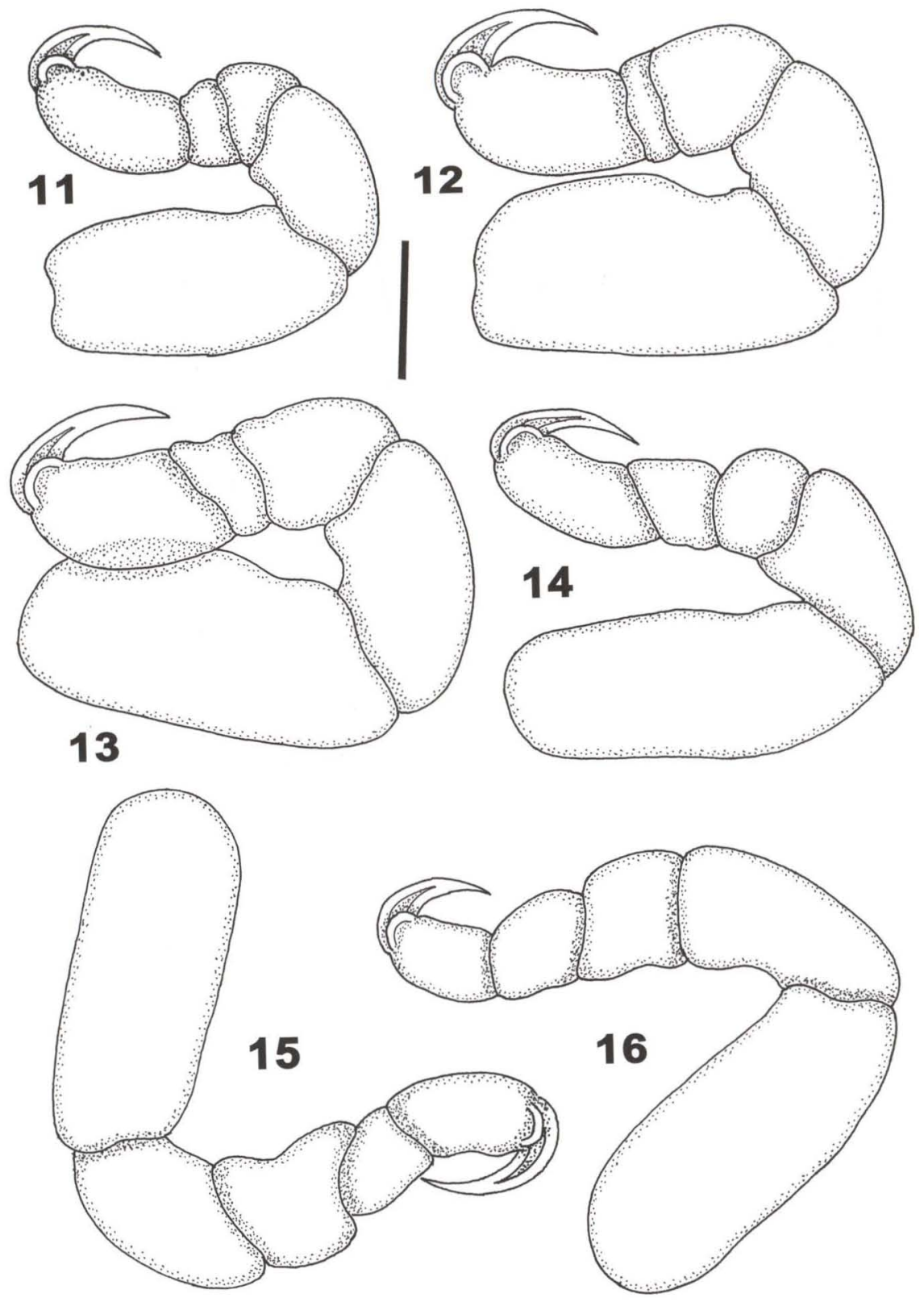

Figs 11-16. Riggia acuticaudata sp. nov., female, pereopods 1-6. Scale $=1 \mathrm{~mm}$. 

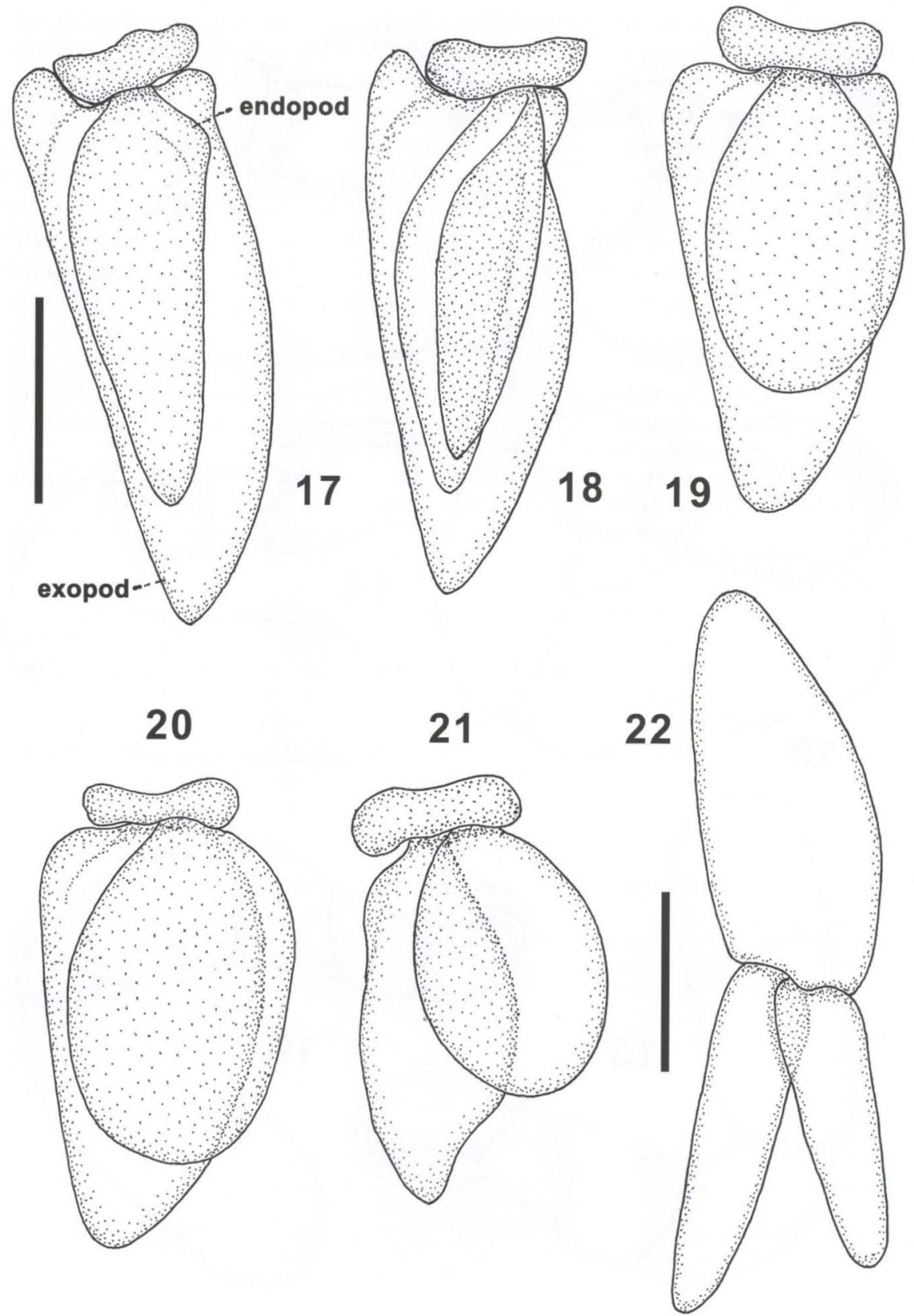

Figs 17-22 Riggia acuticaudata sp. nov., female: (17-21) pleopods 1-5 (dorsal view), scale = $2 \mathrm{~mm}$; (22) uropod, scale $=1 \mathrm{~mm}$. 
tapers abruptly whereas in the other species this unit is "fingernail" shaped and about the same width throughout. The first pereonite of the new species has rounded anterio-lateral margins (Fig. 3) whereas these structures in the other three species are angular. Since the pleon/pleotelson unit tapers in the new species, the first two pleopods also taper which is not the case in the other species. According to THATCHER (1997), the maxillule of Riggia brasiliensis has three terminal and two subterminal spines. The same structure of $R$. paranensis has four terminal and one subterminal spine. The maxillule of the new species has a different arrangement there being two terminal and three subterminal spines. In addition, $R$. acuticaudata sp. nov. is from a different Order of fish host and from a different geographic area.

\section{REFERENCES}

Bastos, P.B. \& V.E. Thatcher. 1997. A redescription of Riggia paranensis Szidat, 1948 (Isopoda, Cymothoidae) based on thirty-two specimens from curimatid fish of Rio de Janeiro, Brazil, with an emendation of the genus. Mem. Inst. Oswaldo Cruz 92: 755-760.

SzIDAT, L. 1948. Riggia paranensis n.g., n.sp., un isópodoparásito de la cavidad del cuerpo de "Curimata platana" Günther, del Rio Paraná. Rev. Inst. Invest. Mus. Argent. Cienc. Nat. 1: 45-56.

Szidat, L. \& O. Schubart. 1960. Neue und seltene parasitische süswasser-Asseln der familie Cymothoidae aus dem Rio Mogi Guassu, Brasilien (Isopoda). Ann. Acad. Brasil. Ciênc. 32: 107-124.

Thatcher, V.E. 1991. Amazon fish parasites. Amazoniana, Ploen, 11: 263-572.

1997. Mouthpart morphology of six freshwater species of Cymothoidae (Isopoda) from Amazonian fish compared to that of three marine forms, with the proposal of Artystonenae subfam. nov. Amazoniana, Ploen, 14: 311-322.

2000. The isopod parasites of South American fishes, p. 193-226. In: G. Salgado-Maldonado; A.N. Garcia-Aldrete \& V.M. Vidal-Martinez (Eds).. Metazoan Parasites in the Neotropics. México, D.F., Univ. Nac. Auton. México Press, 310p.

Received in 10.X.2002; accepted in 27.XI.2002. 